\title{
Mesoscale hydrological variability induced by northwesterly wind on the French continental shelf of the Bay of Biscay
}

\author{
INGRID PUILLAT ${ }^{1}$, PASCAL LAZURE ${ }^{1}$, ANNE-MARIE JÉGOU ${ }^{1}$, LUIS LAMPERT ${ }^{2}$ \\ and PETER MILLER ${ }^{3}$ \\ ${ }^{1}$ IFREMER/Dyneco/Physed, BP 70, 29280 Plouzané, France. E-mail: gridpuillat@yahoo.fr \\ ${ }^{3}$ EPSHOM. BP 426, 29275 Brest Cédex, France. Present address: IFREMER, Av. du Général de Gaulle BP 32, \\ 14520 Port-en-Bessin, France. \\ ${ }^{4}$ Plymouth Marine Laboratory (PML), Prospect Place, Plymouth PL1 3DH, UK.
}

\begin{abstract}
SUMMARY: On the French continental shelf of the Bay of Biscay the variability of the surface salinity distribution has been mainly investigated at the seasonal and inter-annual scales. Here, new mesoscale features such as lower-salinity lenses observed in model results are investigated by hydrological measurements acquired during 8 cruises (1997-2000). These lenses are 50-80 km wide and $\sim 30 \mathrm{~m}$ thick and occur during westerly to northerly wind events that push offshore the less saline water of river plumes. These water masses detached from the coast are replaced with upwelled saltier water at the coast, so coastal upwelling is often observed at the same time along Landes and southern Brittany coasts. We show that in addition to the influence of seasonal and inter-annual variability of the wind and river outflows, short term meteorological variability may drive mesoscale structures on this continental shelf.
\end{abstract}

Keywords: salinity, mesoscale, lens, upwelling, river plume.

RESUMEN: VARIABILIDAD HIDROLÓGICA DE MESOESCALA INDUCIDA POR LOS VIENTOS DEL NOROESTE SOBRE LA PLATAFORMA CONTINENTAL DEL GOLFO DE VIZCAYA. - La salinidad de la plataforma continental francesa del golfo de Vizcaya fue estudiada a escalas anuales e interanuales principalmente. A partir de medidas efectuadas durante ocho campañas marinas (19972000) y del empleo de modelos matemáticos han podido estudiarse nuevas estructuras hidrológicas aisladas de menor salinidad en forma de lentejas. Estas lentejas han medido entre 50 y $80 \mathrm{~km}$ de diámetro y 30 m de espesor. Este fenómeno ha sido observado durante, o después, de fuertes vientos del cuadrante oeste o noroeste que favorecen el desplazamiento del agua desalada de las plumas fluviales hacia el mar abierto. Al separarse de la pluma, estas masas de agua son remplazadas por otra, mas salada, que resurge en la zona costera. De esta manera, puedan observarse simultáneamente afloramientos costeros en las regiónes francesas de Landes y del sur de Bretaña. Se muestra que, además de la variabilidad anual e interanual de los vientos y del caudal de los ríos, los fenómenos meteorológicos a corto plazo pueden condicionar las estructuras hidrológicas de la meso escala de la plataforma continental.

Palabras clave: salinidad, meso escala, afloramientos costeros, pluma fluvial.

\section{INTRODUCTION}

The French part of the Bay of Biscay is situated between the northern Spanish coast and Brittany (Fig. 1). The oceanic part of the bay (depth $>2000 \mathrm{~m}$ ) has been relatively well studied and presented in numerous papers (e.g. Pingree and Le Cann, 1989; Le Cann and Pingree, 1995; Van Haken, 2001). In this area the general circulation is weak (a geostrophic current of $1-2 \mathrm{~cm} \mathrm{~s}^{-1}$ in the surface layer) and anti- 


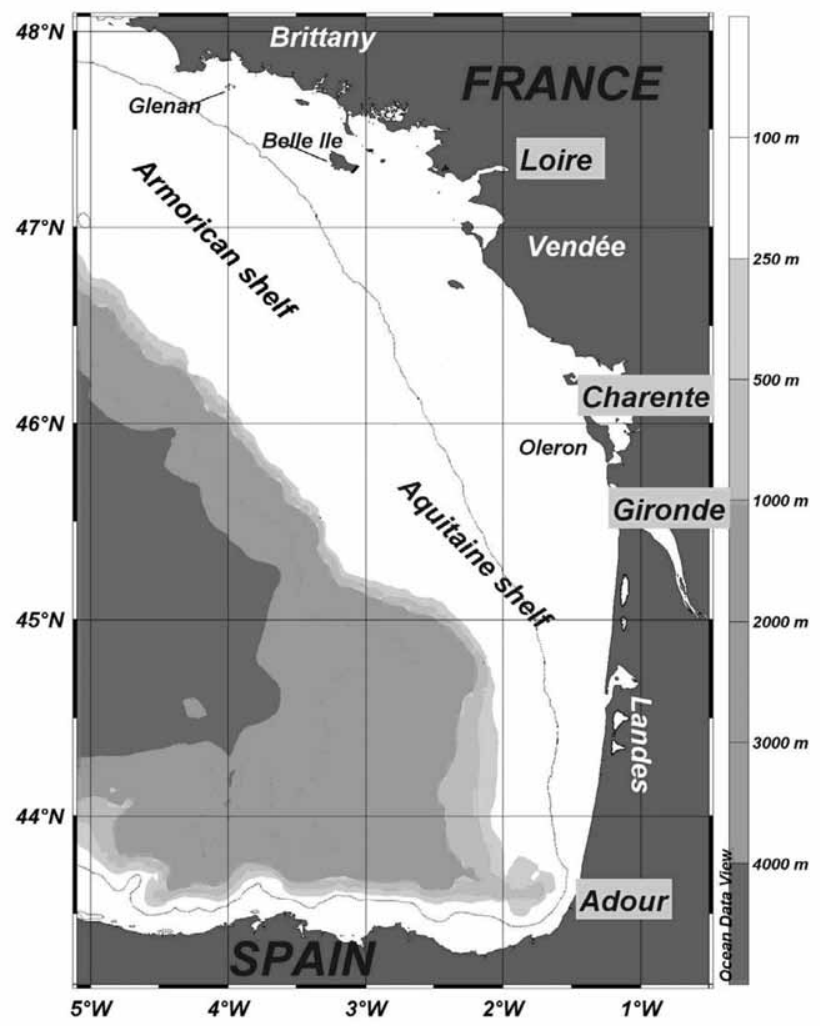

FIG. 1. - Map of the French continental shelf of the Bay of Biscay. River names are in black with a grey background. Glenan, Belle Ile, Oleron, are French islands. Loire, Charente, Gironde, Adour are rivers. Dotted line is $100 \mathrm{~m}$ isobath.

cyclonic. Along the continental slope, the subtidal current measured by current-meters and drifting buoys reaches $\sim 5$ to $\sim 10 \mathrm{~cm} \mathrm{~s}^{-1}$ at $\sim 500 \mathrm{~m}$ depth, and a northward flow is apparent (Pingree and Le Cann, 1990, Le Cann et al., 1997). Unfortunately, observations on the French continental shelf of the bay are scarce (Le Cann, 1982; Pingree and Le Cann, 1989; Koutsikopoulos and Le Cann, 1996; Puillat et al., 2004).

The barotropic tidal characteristics over the French shelf have been investigated by Le Cann (1990): the semi diurnal component $\left(\mathrm{M}_{2}\right)$ is dominant, and instantaneous tidal current strength is correlated with the topography and width of the shelf. Thus, in the southern part of the bay (south of $\sim 45^{\circ} \mathrm{N}$ ) these currents are quite weak, less than $\sim 15 \mathrm{~cm} \mathrm{~s}^{-1}$ (Le Cann, 1990). Over the Armorican shelf, instantaneous tidal currents are stronger $(\sim 30$ $\left.\mathrm{cm} \mathrm{s}^{-1}\right)$ with several maximum local values in the vicinity of islands $\left(>50 \mathrm{~cm} \mathrm{~s}^{-1}\right)$. In this northern part, minimum values $\left(<10 \mathrm{~cm} \mathrm{~s}^{-1}\right)$ are found near the Vendée and the southern Brittany coast between the Glenan and Belle-Ile islands (Pingree et al., 1982; Le Cann, 1990). Tidal residual currents are very weak over the whole continental shelf, so water mass circulation is principally governed by windinduced and density currents.

In this area, the wind has significant variability, as depicted by the frequency distribution of the daily wind direction (Table 1), suggesting that short-term variations may outweigh any seasonal trend. Nevertheless, when the mean wind stress is calculated (which gives greater significance to the wind speed), northwesterly wind stress is dominant from spring to late summer, and southwesterly wind stress from autumn to early spring (Le Cann and Pingree, 1995). A primary characteristic is a relatively rapid response of shelf waters to steady wind stress. Analysis of the wind-driven response on the Armorican and Celtic shelves $\left(43-53^{\circ} \mathrm{N}\right)$ shows that NW winds create the largest current response (Pingree and Le Cann, 1989). The NW wind induces SW-S surface currents over the French shelf. The SW wind reverses the circulation towards the northwest and the transport is limited. Over the Armorican shelf and the northern part of the Aquitaine shelf, the currents generated are typically $\sim 10 \mathrm{~cm} \mathrm{~s}^{-1}$ and locally $20-30 \mathrm{~cm} \mathrm{~s}^{-1}$. In the southeastern part of the bay the situation is more complex: the circulation over the slope should affect this area because of the narrow width of the continental shelf. Wind-induced mesoscale variability near the coast and over the shelf is poorly documented; only wind-induced upwelling along the Landes and Vendée coast has been described. (Pingree, 1984; Froidefond et al., 1996). Jégou and Lazure (1995) showed that vertical movements induced by upwelling-favourable winds are stronger when tidal currents are weak. Accordingly, the Landes, the

TABLE 1. - Frequency (\%) of daily wind directions measured at Chassiron with mean intensity in $\mathrm{m} \mathrm{s}^{-1}$ (italic) over the $1980-2000$ period

\begin{tabular}{lcccccccc}
\hline & NE & E & SE & S & SW & W & NW & N \\
\hline Winter & 16.75 .9 & 9.64 .1 & 9.44 .3 & 13.16 .1 & 18.47 .8 & 12.77 .5 & 10.16 .7 & 10.06 .7 \\
Spring & 14.35 .6 & 5.63 .9 & 3.64 .1 & 7.95 .0 & 15.96 .5 & 16.16 .2 & 20.85 .4 & 15.84 .9 \\
Summer & 11.35 .0 & 4.14 .0 & 2.73 .6 & 5.24 .6 & 12.86 .1 & 18.95 .3 & 27.44 .8 & 17.64 .3 \\
Autumn & 16.16 .3 & 13.25 .0 & 12.34 .6 & 12.85 .9 & 16.88 .2 & 12.38 .1 & 7.87 .3 & 8.76 .2 \\
\hline
\end{tabular}


Vendée and the south Britanny coasts should be the most sensitive areas. In agreement with Ekman's theory, northwesterly to northerly winds induce upwelling in the south part of the Loire because the coastline is actually oriented N-S, whereas westerly to northwesterly winds generate upwelling to the north of the Loire as the coastline is oriented NWSE (Lazure and Jégou, 1998).

Density currents are observed in the vicinity of estuaries, as freshwater rivers discharge into the surface layers. The Loire and the Gironde are the two main rivers on France's Atlantic coast. Their annual mean outflow is about $900 \mathrm{~m}^{3} \mathrm{~s}^{-1}$. Each of them has peak runoff in winter or spring exceeding $\sim 3000 \mathrm{~m}^{3}$ $\mathrm{s}^{-1}$ and a minimum in summer of about $200 \mathrm{~m}^{3} \mathrm{~s}^{-1}$. The influence of other rivers such as the Adour and Vilaine is lesser but still significant. Thus, all these river discharges can induce significant density currents (from model: $\sim 10 \mathrm{~cm} \mathrm{~s}^{-1}$, Lazure and Jégou, 1998), which are often modified by the windinduced circulation as shown by modelled plumes (Jégou and Lazure, 1995; Lazure and Jégou, 1998) and NOAA/AVHRR visible and infrared images (Jégou and Lazure, 1995; Froidefond et al., 1998; Hermida et al., 1998). In winter southwest winds are more frequent and river runoff is high, so the plumes usually spread northwards and alongshore. In spring river runoff begins to fall and prevailing winds become northwesterly (upwelling-favourable) until late summer. The timing of these changes is unpredictable, and after them the plumes are mainly driven offshore or southward and low salinity may cover a majority of the continental shelf (Lazure and Jégou, 1998). This situation is most common in summer, though with higher salinity than in spring. This seasonal variability has recently been confirmed through analysis of in situ hydrographical measurements (Puillat et al., 2003, 2004).

This literature review reveals that except for Landes coastal upwelling and river plumes the occurrence of mesoscale variability on the French shelf is poorly documented because most published hydrological data are historical, with sampling that is not synoptic enough to include mesoscale features. Structures such as lower-salinity lenses were suggested by modelling the hydrodynamics of the Bay of Biscay (Lazure and Jégou, 1998) and other coastal areas (Chen et al., 1999). These facts led us to focus on salinity distribution over the French continental shelf using hydrological (CTD) in situ data acquired between 1992 and 2000 on the Bay of
TABLE 2. - Selected cruises on the French continental shelf of the Bay of Biscay

\begin{tabular}{lcc}
\hline Cruises & Date dd/mm/yy & $\begin{array}{c}\text { numbers of } \\
\text { CTD casts used }\end{array}$ \\
\hline MODYCOT 97-1 & $27-29 / 06 / 97$ & 20 \\
MODYCOT 97-2 & $15-16 / 12 / 97$ & 12 \\
MODYCOT 98-3 & $22-27 / 04 / 98$ & 47 \\
MODYCOT 98-4 & $07-16 / 09 / 98$ & 38 \\
MODYCOT 99-1 & $07-13 / 04 / 99$ & 35 \\
MODYCOT 99-2 & $07-15 / 06 / 99$ & 38 \\
MODYCOT 99-3 & $07-14 / 09 / 99$ & 46 \\
MODYCOT 00-1 & $01-06 / 03 / 00$ & 41 \\
\hline
\end{tabular}

Biscay French continental shelf. Even though salinity measurements on the French shelf are scarce, these data have already allowed us to study the seasonal and inter-annual salinity variability (Puillat $e t$ al., 2003, 2004). Among the available data, the Modycot cruises (EPSHOM/CMO) showed the highest temporal and spatial resolution $(30-40 \mathrm{~km}$ along and across transects) of the sampling field. They covered a large part of the French shelf over a week, two or three times a year from 1997, so they provide the most appropriate data for describing mesoscale structures. Therefore, data from 8 cruises were selected from 1997 to 2000 for this study (Table 2). By analysing this data set, this article examines mesoscale structures mainly induced by northwesterly winds: southern Brittany upwelling and lower-salinity lenses. The observations are described in the next Section. Then, the processes involved and biological consequences are discussed. Finally, the conclusion highlights the links between mesoscale salinity variability and greater scales (time and space) of salinity distribution.

\section{OBSERVATIONS}

\section{Southern Brittany upwelling}

An example of a southern Brittany upwelling event is provided by the Modycot 97-1 (June 1997) surface temperature distribution (Fig. 2a). An increase of $0.5-0.6^{\circ} \mathrm{C}$ was observed at the surface between the point closest to the coast $\left(14.9^{\circ} \mathrm{C}\right)$ and the nearest offshore point $\left(15.5^{\circ} \mathrm{C}\right)$ situated $\sim 30 \mathrm{~km}$ away (the first two stations on the Fig. $2 \mathrm{~b}$ transect). At $20 \mathrm{~m}$ depth, the horizontal thermal gradient was stronger, more than $1.3^{\circ} \mathrm{C}$ over $\sim 30 \mathrm{~km}$ (Fig. 2b). This upwelling induced $14^{\circ} \mathrm{C}$-water to rise from $\sim 40 \mathrm{~m}$ to $\sim 20 \mathrm{~m}$ depth over $\sim 30 \mathrm{~km}$. Its cross-shore 

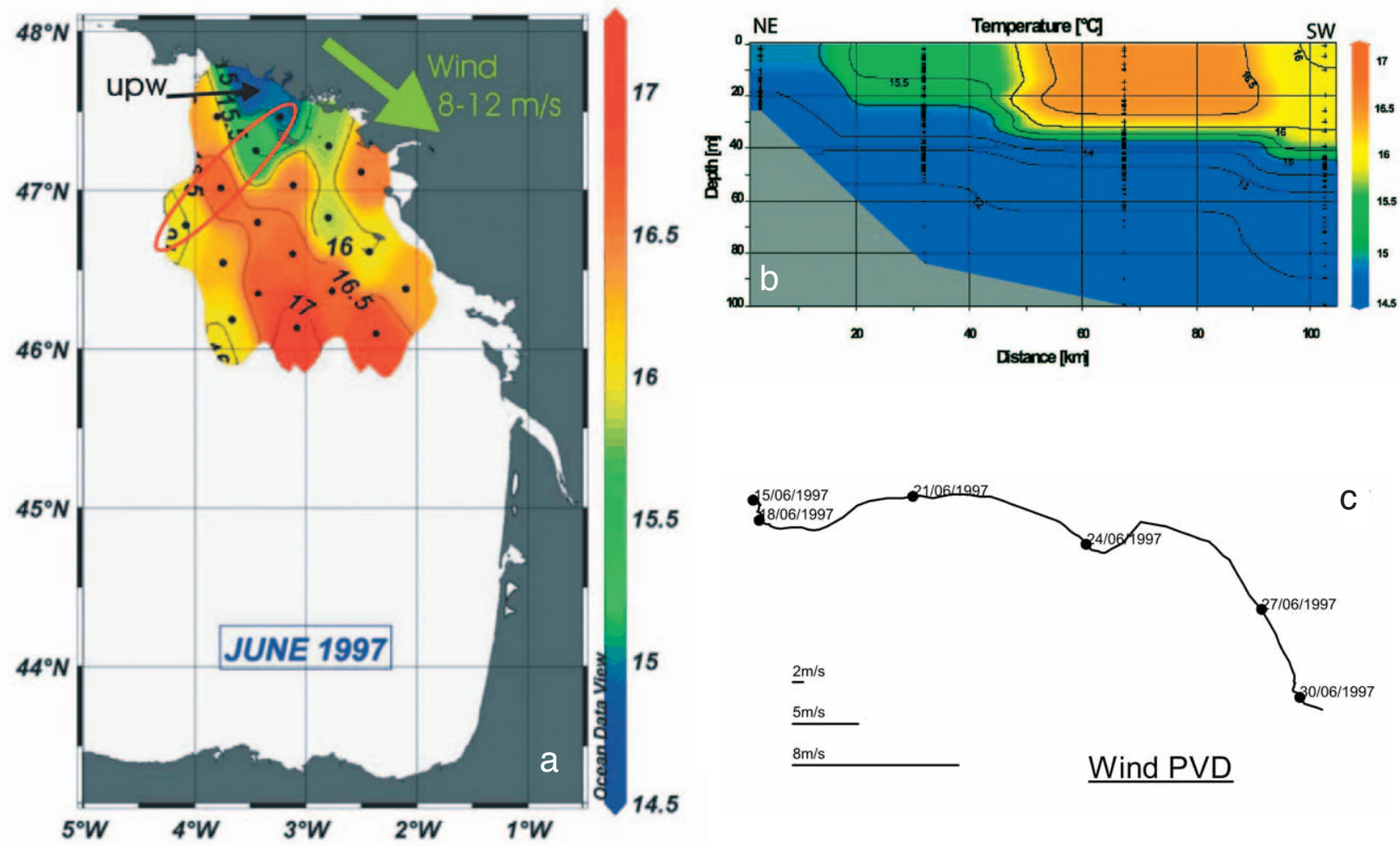

$5 \mathrm{~m} / \mathrm{s}$

$\underline{\text { Wind PVD }}$

FIG. 2. - Southern Brittany upwelling observed during the Modycot 97-1 cruise (June 1997) on a surface temperature distribution (a). The red ellipse corresponds to the selected points for the vertical temperature transect (b). Wind direction and intensity recorded at "Belle Ile" at the end of June 1997 are represented on the Progressive Vector Diagram (PVD) (c).

extent cannot be defined with good accuracy because in this direction the upwelling was only apparent at one or two points. A sampling interval of $30-40 \mathrm{~km}$ in the offshore direction is not well adapted to sampling a phenomenon extending offshore only $\sim 50 \mathrm{~km}$. A westerly wind event $\left(\sim 8 \mathrm{~m} \mathrm{~s}^{-1}\right)$ started one week before the cruise began, and then the wind turned northwesterly (Fig. 2c).

Similar local structures were observed on NOAA/AVHRR infrared images, for example on 15-17 June 1998 (Fig. 3a). On this composite image the coldest surface water $\left(\mathrm{T}<15^{\circ} \mathrm{C}\right)$ lies along the southern Brittany coast, and warmer water ( $\mathrm{T}$ $<17^{\circ} \mathrm{C}$ ) is observed up to the mid shelf, $\sim 100 \mathrm{~km}$ offshore from southern Brittany and along the coast up to the Gironde estuary. Over the same period, recorded winds were westerly then northwesterly $\left(\sim 8 \mathrm{~m} \mathrm{~s}^{-1}\right)$ for 5-6 days (Fig. 3b).

From these observations it can be inferred that southern Brittany upwelling is linked to westerly to northwesterly winds. In this coastal area, tidal currents are weak (Pingree et al., 1982), allowing strong stratification in spring and the development of an Ekman layer which is well separated from the bottom layer. These observations support the model results of Lazure and Jégou (1998) for the different wind directions that can induce upwelling along the French Atlantic coast (see Introduction Section).

\section{Lower-salinity lenses}

Lower-salinity lenses are mesoscale structures with lower salinity in their core than the surrounding water. They are observed on the shelf, i.e. in water up to $\sim 200 \mathrm{~m}$ depth. Of several lower-salinity lenses observed, the most relevant occurred during the Modycot 98-4 cruise in September 1998 and the Modycot 99-3 cruise in September 1999. They are respectively called L1 and L2. Four other lenses, S1, S2 (Modycot 99-1, April 1999) and S3, S4 (Modycot 99-2, June 1999) are also presented. During Modycot 97-2, the sampled area was much too small to allow a lens observation. No lens was observed during Modycot 99-1, 98-3, and 00-1, and this result is discussed in the Discussion Section.

\section{Lens L1, Sept. 1998}

In the September 1998 surface salinity distribution the L1 lens contains values lower than 35.1 sur- 

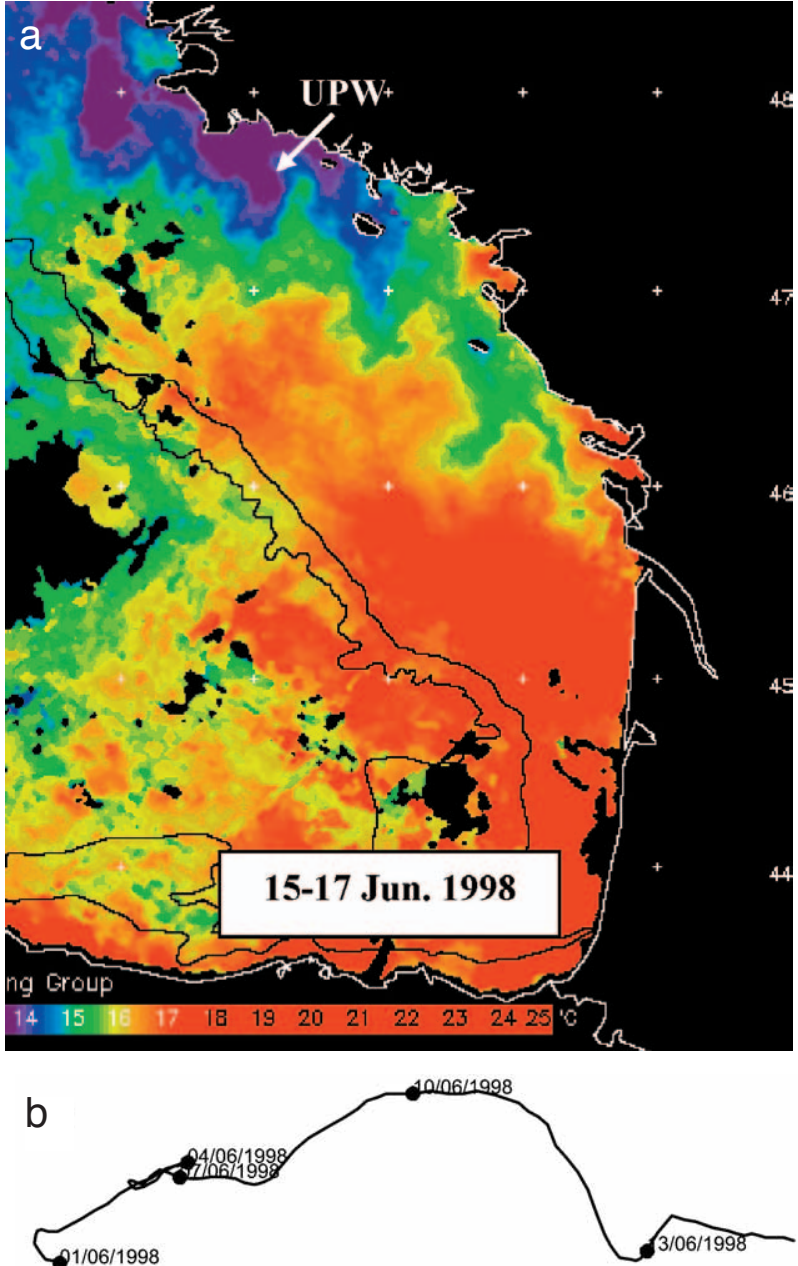

$\underline{2} \mathrm{~m} / \mathrm{s}$

$\underline{5 \mathrm{~m} / \mathrm{s}}$

$8 \mathrm{~m} / \mathrm{s}$

Wind PVD

FIG. 3 - Composite NOAA/AVHRR SST image from 15-17 June 1998 (a) (from RSDAS, Plymouth) UPW=southern Brittany upwelling. Wind direction and intensity recorded at the beginning of June 1998 are represented on the Progressive Vector Diagram (PVD) (b).

rounded by 35.1-35.4, located in the Gironde area around $46^{\circ} \mathrm{N}$ (Fig. 4a). Its contour is almost the same from the surface to at least $20 \mathrm{~m}$ (Fig. 4b). On a vertical transect $\mathrm{L} 1$ is characterised by isolines deepening towards the centre in the surface $30 \mathrm{~m}$, and its diameter reached $\sim 80 \mathrm{~km}$ considering the 35.1-35.2 isohalines (Fig. 5). Near the surface, a horizontal increase of $\sim-0.3$ in salinity $(0.007-0.008$ $\left.\mathrm{km}^{-1}\right), 1.3^{\circ} \mathrm{C}$ and -0.5 in density were observed between the most coastal CTD cast (P) and the nearest offshore cast $(\mathrm{Q}) \sim 40 \mathrm{~km}$ away. Even though the chosen transect was performed in one day, interpolation is unsatisfactory due to the $\sim 40 \mathrm{~km}$ sampling interval. Although L1 was observed on the along-
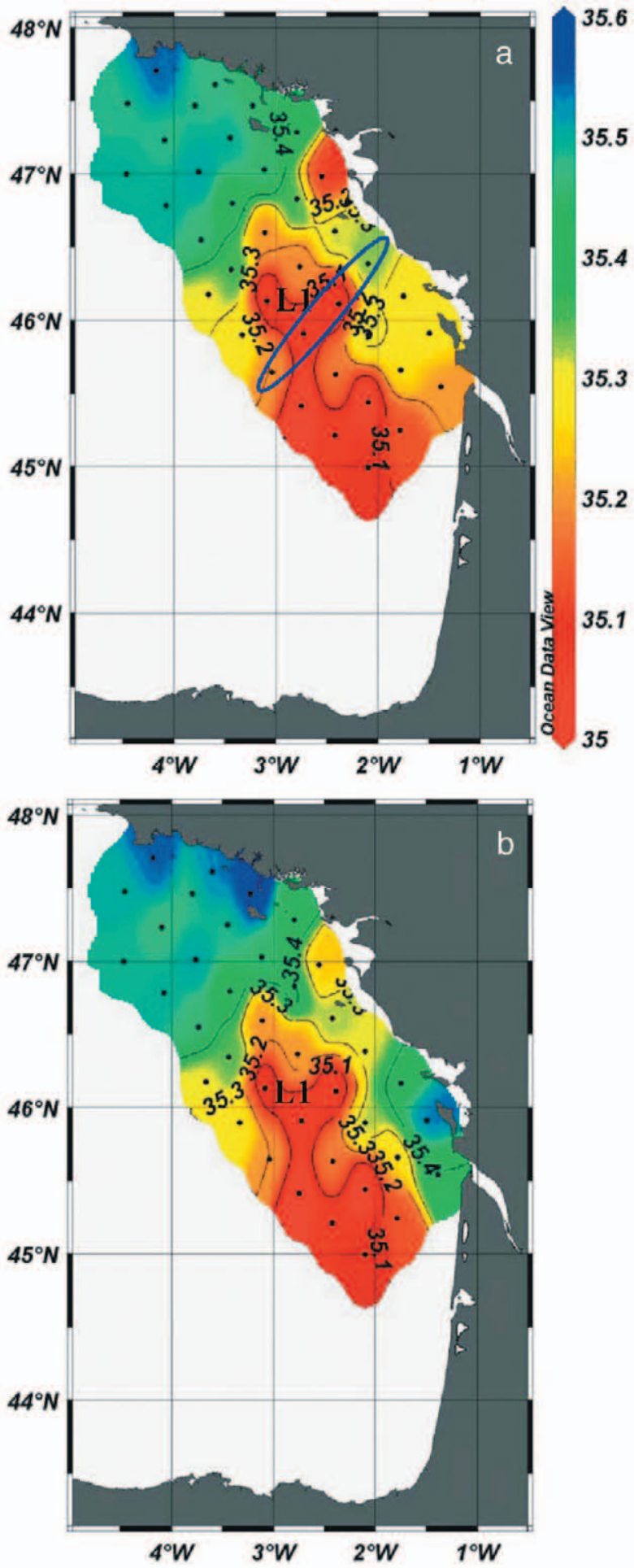

Fig. 4. - Surface (a) and $20 \mathrm{~m}$ (b) salinity distributions calculated from the Modycot 98-4 survey (September 1998). L1= lower salinity lens. The blue ellipse corresponds to selected points for the vertical section shown in Fig. 5.

shore and cross-shore transects, we searched for its signature on infrared images for confirmation. The closest cloud-free image was acquired on 18 

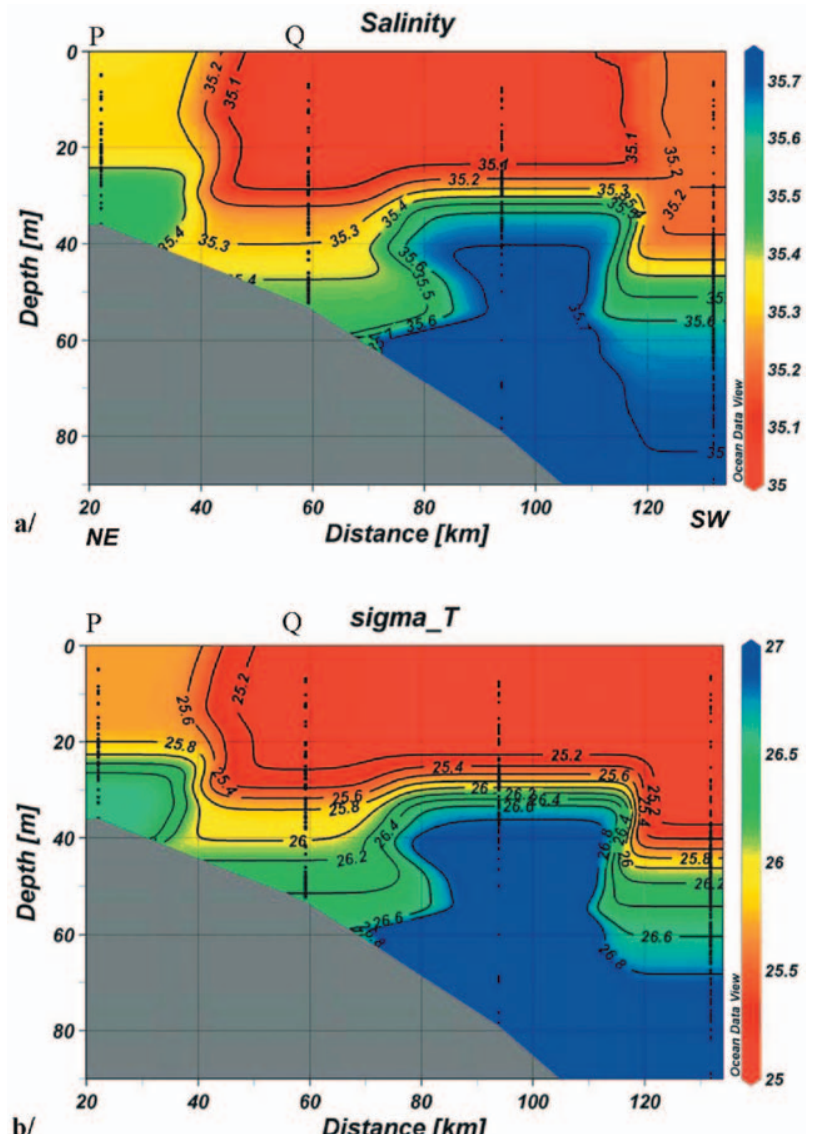

FIG. 5. - Salinity (a) and Sigma-T (b) vertical section across the L1 lens during the Modycot 98-4 survey (September 1998). P and Q are two CTD casts.

September, one week after in situ measurements, where L1 is visible further northwest (Fig. 6). Consequently, this lens persisted for at least one week. Some upwelling events were also observed along the southern Brittany coast and the Vendée coast and some colder water reached the southern Loire estuary (Fig. 6). During L1 sampling (11-12 September) the wind was mainly NW at $8-12 \mathrm{~m} \mathrm{~s}^{-1}$ (Fig. 7). Note that similar wind events also occurred between 20 and 26 August 1998.

\section{Lens L2, Sept. 1999}

Modycot salinity distributions reveal variability in the diameter, shape, mean depth and intensity of different lower-salinity lenses. For instance, in comparison with L1, lens L2 has a lower minimum salinity of 34.4 in its core near the surface and a lower surface salinity gradient $\left(\sim 0.006 \mathrm{~km}^{-1}\right)$ (Fig. 8). If 35.1- 35.2 salinity values are taken as the boundary of $\mathrm{L} 1$ and $\mathrm{L} 2$, the L2 shape near the bottom $(30-40 \mathrm{~m})$ is also completely different from that of L1. At this depth,

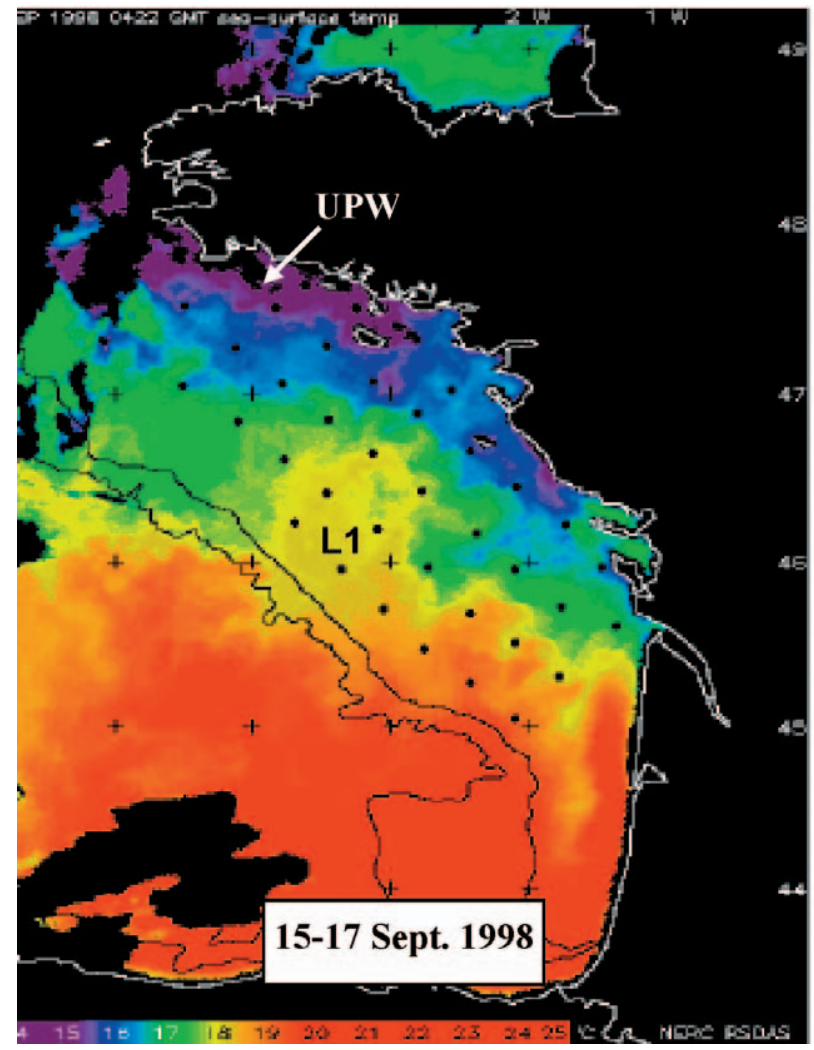

FIG. 6. - NOAA/AVHRR SST image from 18 September 1998 (RSDAS, Plymouth) and sampling points of the Modycot 98-4 survey. $\mathrm{L} 1=$ lower salinity lens, UPW= upwelling from the Vendée coast to the southern Brittany coast.

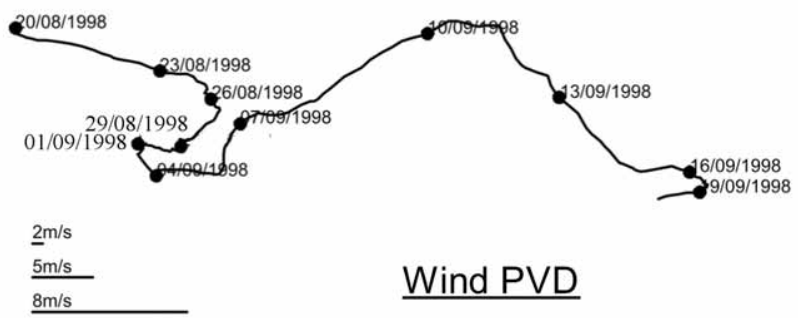

FIG. 7. - Progressive Vector Diagram of wind recorded from 20 Aug. to end of Sept. 1998 at "Belle Ile".

water of L2 extends more than $50 \mathrm{~km}$ to the NW (Fig. $8 \mathrm{~b}$ and $8 \mathrm{c}$ ). This results in a lens structure which is horizontally larger at $40 \mathrm{~m}$ than in the surface layer (comparing Figs. 8a and 8b).

\section{Lenses S1-S2 (Apr. 1999) and S3-S4 (Jun. 1999)}

Some other lens signatures were suggested by the 20-40 m salinity distributions for the Modycot 99-1 cruise in April 1999 (S1 and S2 on Fig. 9), and for the Modycot 99-2 cruise in June 1999 (S3 and S4 on Fig. 10). S1 corresponded to a salinity 


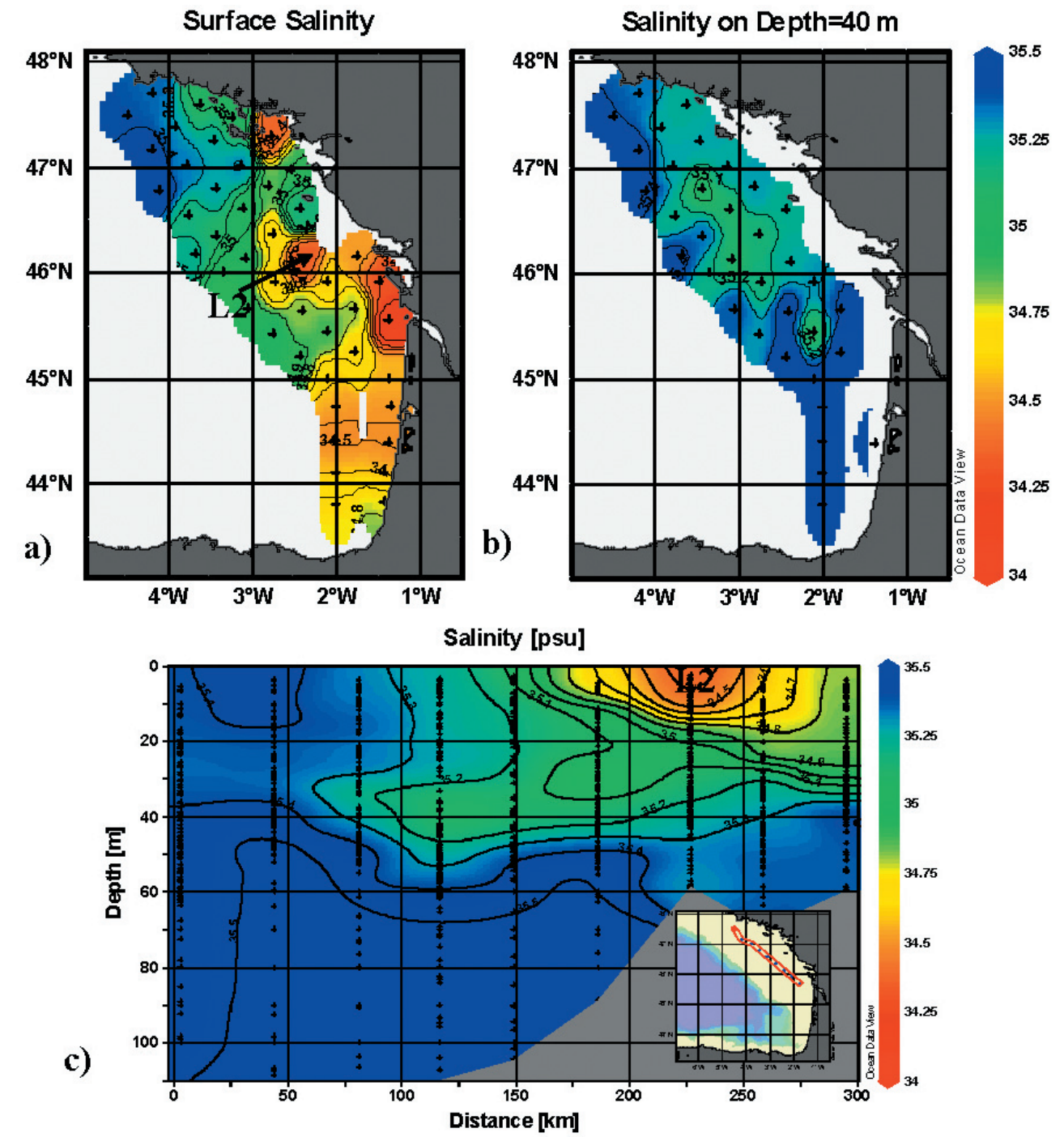

FIG. 8. - Surface (a) and 40m (b) salinity distributions calculated from the Modycot 99-3 survey (September 1999) and alongshore salinity vertical section (c). L2 $=$ lower salinity lens.
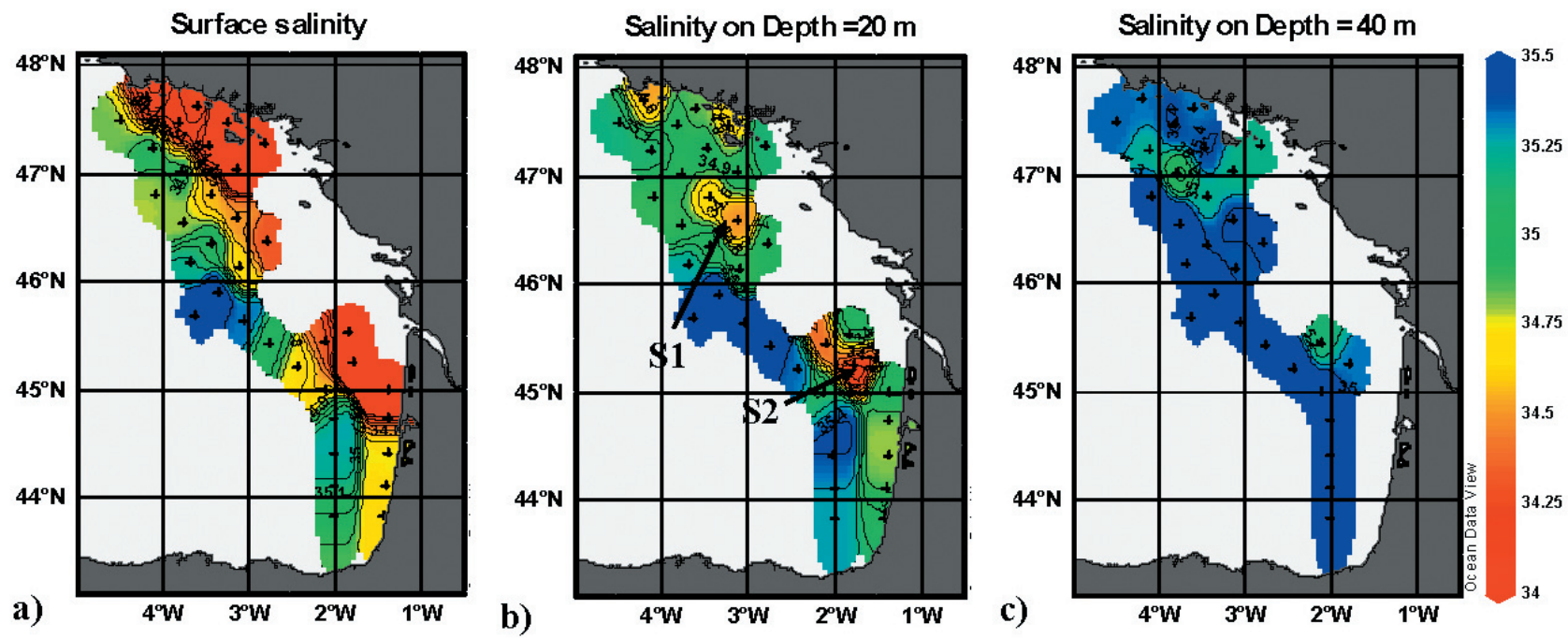

FIG. 9. - Salinity distributions calculated near the surface (a), at $20 \mathrm{~m}$ (b) and $40 \mathrm{~m}$ (c), from the Modycot 99-1 survey (April 1999). S1 and S2 are two salinity structures. 

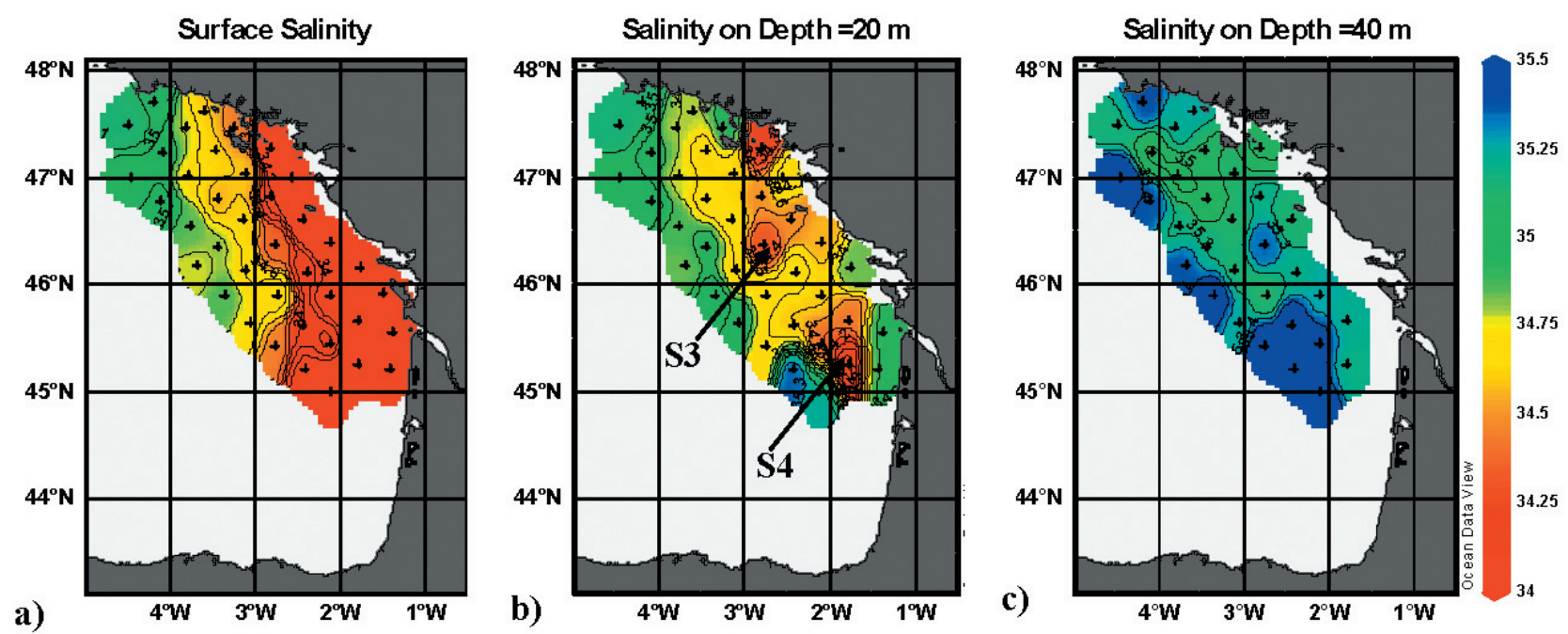

FIG. 10. - Salinity distributions calculated near the surface (a), and at $20 \mathrm{~m}$ (b) from the Modycot 99-2 survey (June 1999). S3 and S4 are two salinity structures.

gradient of $\sim 0.014 \mathrm{~km}^{-1}$ between its central point and the nearest offshore point ( $\sim 0.5$ over $35 \mathrm{~km})$. $\mathrm{S} 2$ induced a $\sim 0.020 \mathrm{~km}^{-1}$ gradient and S4 a $\sim 0.010$ $\mathrm{km}^{-1}$ gradient. The $\mathrm{S} 4$ structure displayed the largest salinity gradient with $\sim 0.035 \mathrm{~km}^{-1}$ (32.834.9 ) over $\sim 60 \mathrm{~km}$ at $20 \mathrm{~m}$, and a diameter of $\sim 50 \mathrm{~km}$ from east to west.

\section{DISCUSSION}

\section{Hypotheses of processes}

During L1 observations (Modycot 98-4, 07-16 Sept. 1998) NW winds (8-12 $\left.\mathrm{m} \mathrm{s}^{-1}\right)$ were established from 11 September (Fig. 7). For L2 (Modycot 99-3, 07-14 Sept. 1999) prevailing winds varied between northerly and northwesterly and were weak from 20 August to 11 September (not shown). Between 13 and 16 September 1999, the wind strengthened and an upwelling was observed along the Landes coast on infrared images (not shown). S1-S4 were also observed during upwelling-favourable wind events. During S1-S2 observation (Modycot 99-1, 07-13 Apr. 1999), a strong NW wind $\left(8-12 \mathrm{~m} \mathrm{~s}^{-1}\right)$ was recorded from the beginning of the cruise. During S3-S4 sampling (Modycot 99-2, 07-15 Jun. 1999), the wind was westerly during the first 3 days, then northerly (therefore also upwelling-favourable) but weaker $\left(\sim 5 \mathrm{~m} \mathrm{~s}^{-1}\right)$.

Considering those facts, our hypothesis is that NW wind can push offshore the fresher water issued from river plumes. This water detached from the coast is replaced with upwelled saltier water at the coast, resulting in a lens of fresher water isolated from the shore. However this appears to be contradicted by L1 observations, as NW wind $\left(8-12 \mathrm{~m} \mathrm{~s}^{-1}\right)$ was established for less time than the inertial period so should not alone have been able to generate and transport a lens. In addition, the Loire and Gironde runoffs since mid-May 1998 were lower than the annual average. Indeed, monthly averages of Loire and Gironde runoffs decreased respectively from $\sim 460$ and $\sim 530 \mathrm{~m}^{3} \mathrm{~s}^{-1}$ in June to $\sim 195$ and $\sim 235 \mathrm{~m}^{3} \mathrm{~s}^{-1}$ in September. L1's creation is probably related to a more complex hydrodynamical situation: perhaps a rapid response to NW wind can also be linked to the area's past dynamic state. For instance, the NW wind event $\left(>8 \mathrm{~m} \mathrm{~s}^{-1}\right)$ recorded on 20-26 August 1998 could have created a greater sensitivity for the following NW wind event in September (Fig. 7). Thus, this lens could have been initiated before the onset of the wind event during the cruise. Our hypothesis is applicable to L2 as winds were strong enough to induce upwelling (Fig. 8). The calculated Ekman depth is $\sim 20 \mathrm{~m}$, meaning that the first $20 \mathrm{~m}$ are wind-induced, and that other processes may be involved in the deeper part of L2 where its horizontal extent is different. The upper situation corresponds to recent southwestward transport of lowsalinity surface water due to NW wind, whereas the deeper layer corresponds to older, and so more mixed, water which has been overlaid by more recent fresher water. In this case the low-salinity water at 30-40 m observed 100-150 km off the Loire and Vendée coasts may be the sign of an older situ- 
TABLE 3. - Monthly river runoff in 1999-2000 $\left(\mathrm{m}^{3} \mathrm{~s}^{-1}\right)$

\begin{tabular}{lcc}
\hline & Loire & Gironde \\
\hline October & 601 & 591 \\
November & 805 & 927 \\
December & 1943 & 1482 \\
January & 2079 & 1080 \\
February & 1425 & 1301 \\
March & 1293 & 1134 \\
\hline
\end{tabular}

ation. This underlines the lack of information about plume hydrodynamics.

S1-S4 observed in spring had higher gradients than L1 and L2 observed in summer. In summer, river runoff is low so the plume is smaller and more diluted, and lenses isolated in summer should have lower gradients than in spring. The other main difference is that $\mathrm{S} 1-\mathrm{S} 4$ were not observed at the surface. This can be explained both by upwellingfavourable winds observed during measurements and by high river runoff from winter to spring, inducing fresher water to cover a majority of the shelf and obscure any lenses at the surface. This situation was particularly apparent during Modycot 00-1 in March 2000 and Modycot 99-1 in April 1999. During Modycot 00-1 salinity was lower and the thickness of the layer was greater, due to high runoff lasting at least 4 months (see Table 3 ), with a daily maximum of $5050 \mathrm{~m}^{3} \mathrm{~s}^{-1}$ for the Loire and $2160 \mathrm{~m}^{3} \mathrm{~s}^{-1}$ for the Gironde. River runoff should temporarily decrease and/or upwelling-favourable wind should be stronger in order to generate a surface lens and transport it away from the low-salinity strip: this can occur during the spring (Puillat et al., 2004). For instance, in 1999 river levels started to fall in June, so S3-S4 (June 1999) may represent the beginning of this process. S1 and S2 observed earlier (April 1999) may be created by different processes such as mixing/deepening of isopycnals induced by internal waves, as already observed on the shelf close to the shelf break (Lampert et al., 2002). Indeed, during periods of thermo-haline stratification, internal waves are expected to induce shearing and mixing at the pycnocline interface (Mazé, 1987; Jezequel et al., 1998). Nevertheless this has never been observed in an area as close to the coast as S1 and S2.

Our hypothesis is reinforced by the fact that in response to SW wind events during Modycot 98-3 (22-27 Apr. 1998) river plumes were distributed in a band along the coast and no lens was observed. Indeed, SW wind blew continuously during the cruise with 5-12 $\mathrm{m} \mathrm{s}^{-1}$ on 19-28 April 1998 and also before the cruise with 8-20 $\mathrm{m} \mathrm{s}^{-1}$ on 1-7 April 1998. In contrast, it should be noted that in spite of upwelling-favourable wind occurring during Modycot 97-1, no lens was observed. This can be linked to the northern position of the sampled area: a lens created at Loire plume latitude should travel northward, which is improbable because of the NW wind (SW transport).

All these facts underline the great importance of river discharge and upwelling-favourable winds (NW) in creating lower-salinity lenses on this shelf. This result is not isolated: similarly, Froidefond et al. (1996) observed a body of less salty water $(\mathrm{S}<33.4) \sim 30 \mathrm{~km}$ offshore from the Landes coast in the surface layer during a northerly upwellingfavourable wind event in July 1989 (an upwelling was also seen). It was assumed that this less salty water originated from the Gironde. Further south, Uriarte et al., (2001) depicted wind-induced lowersalinity lenses on the Spanish part of the Bay of Biscay in the summer of 1998 and 1999. Such observations have also been reported in the South Atlantic Bight (SAB, southeast United States continental shelf: $27^{\circ} \mathrm{N}-35^{\circ} \mathrm{N}$ ), where winter and spring circulation of water masses on this shelf is similar to that of the Bay of Biscay. Twelve rivers along $400 \mathrm{~km}$ of coastline produce a total runoff varying from $\sim 1000$ to $\sim 4000 \mathrm{~m}^{3} \mathrm{~s}^{-1}$ in spring. In winter river discharges from the coast form a frontal zone which extends $\sim 20 \mathrm{~km}$ offshore. In spring and summer, prevailing SW winds are upwelling-favourable on this eastern coast. There, similar lenses have been observed on the shelf with hydrographic measurements (Blanton et al., 1989; Paffenhöfer et al., 1994). It is reported that in spring and summer, when upwelling-favourable wind prevails over the shelf, some relatively fresh lenses $(S \sim 0.2)$ could form at the outer edge of the low-salinity front (due to a river plume). This observation was also depicted by 2-D model results performed on the SAB by Oey (1986) and Blanton et al., (1989), and 3-D model experiments (Chao, 1987, 1988). Lenses were also revealed by a modelling study of windinduced water removal from the inner shelf region of the SAB (inner shelf: $\mathrm{z}<20 \mathrm{~m}$ ) in spring 1984 (Kourafalou et al., 1996a, b). For all those results, the proposed descriptions are consistent with ours: they found that an isolated lower-salinity lens could form at the outer edge of the density front as a result of upwelling-favourable wind which induces 
upwelling events. In the outer or mid-shelf ( $z>20 \mathrm{~m}$ ) this is consistent with Ekman's theory, which is applicable in areas where the bottom friction has negligible effects on the surface layer. However, on the inner shelf $(\mathrm{z}<20 \mathrm{~m})$ the process involved should be more complex. Using a 3-D model adapted for the SAB inner shelf, Chen et al. (1999) and Chen (2000) studied the influence of wind, river discharge and tidal mixing on lower-salinity lenses formation and isolation on the inner shelf. They suggested that lens formation at the outer edge of the low-salinity front is controlled by processes associated with along-shelf advection and vertical diffusion. In our case processes involved on the inner shelf could be similar to that depicted by Chen, but our sampling field does not permit a fine enough specific description to fully explain generation mechanisms.

\section{Physical and biological consequences}

\section{Physical consequences}

The dynamic consequences of lenses are suggested by the vertical transects (Fig. 5 and 7c). Isolines deepening towards the centre correspond to the signature of an anticyclonic eddy in the context of geostrophic approximations. For L1, the induced variation of geostrophic current $\Delta \mathrm{v}_{\mathrm{g}}$ is estimated to be $\sim 0.03 \mathrm{~m} \mathrm{~s}^{-1}$ (at $\mathrm{z}=20 \mathrm{~m}$, between the points $P: \rho_{1}=25.8$ and $Q: \rho_{2}=25.2$ on Fig. 5). This value shows that the density gradient due to lens L1 could induce significant current variation. From modelling, Chen (2000) considers that the lens develops an eddy-like structure after the wind subsides through adjustment of surface elevation by geostrophic currents. The residence time of these eddies depends on their initial strength and location: in areas of weak tidal mixing they can last about one week. This residence time corresponds to L1 observation.

\section{Biological consequences}

Concerning the mesoscale influence, Motos et al. (1996) showed that Bay of Biscay anchovy select stable habitats related to river plumes, shelf edge fronts and oceanic eddies, where increased biological production may occur. River plumes generate low-salinity water with a high rate of warming during the spring transition (shallow thermocline) and higher lithogenic nutrient concentrations. The resulting stratification induces stabilisation of the water column, which may allow the generation and maintenance of food particles required for the survival of feeding larvae. Motos et al. (1996) also observed that anchovy eggs and larvae first occurred in great abundance when the sea-surface temperature rose above $14^{\circ} \mathrm{C}$. Consequently, the high rate of warming in river plumes should also be favourable for anchovy egg survival. As in river plumes, high numbers of anchovy eggs have sometimes been found in isolated lower-salinity lenses far away from the coast. This results in significant patchiness in egg distribution, also observed by Sanchez and Gil (2000) along the Cantabrian coast (southern Bay of Biscay). In contrast, high salinity water intrusions in coastal surface areas do not usually contain anchovy eggs. This association between the distribution of spawning activity and areas influenced by river outflows has already been described for several species. For instance, this was the case in the northwestern Mediterranean with in situ measurements (Palomera, 1992), and in the Baltic sea by combining a physical model and a field sampling programme (Hinrichsen et al., 1997). Results from Porch (1998; also Lee et al., 1992 and 1994) emphasise the influence of mesoscale structures such as meanders and eddies as retention systems for larval fish associated with the poleward current along the southern Florida coast. Numerous references can be found concerning eddy influence on fish larvae and eggs (e.g., Penven et al., 2000; Herman et al., 1995; Shumacher et al., 1993). In the oceanic domain of the Bay of Biscay, the influence of eddies called SWODDIES (by Pingree and Le Cann, 1992) was investigated by Bartsch et al. (1996) with model results. Lenses described in this article have an eddy-like structure, so they are expected to behave like retention systems for larvae and eggs; a study of this is being carried out.

\section{CONCLUSION}

This article highlights the importance of mesoscale hydrodynamic variability over the French continental shelf of the Bay of Biscay. Examples of southern Brittany upwelling and some lower-salinity lenses have been presented. Surface lower-salinity lenses were observed during upwellingfavourable wind events, pushing fresher water offshore and inducing coastal upwelling, but more 
complex processes may take place. Thus, relatively short-period wind variability may drive mesoscale circulation over the shelf.

It is also shown that the generation of these lenses, in terms of isolated structures on the shelf, can be difficult when low-salinity water $(\mathrm{S}<35)$ covers the majority of the shelf, as can happen in spring. Also, considering that NW wind is predominant from early spring to the end of summer, the seasonal trend in meteorological forcing (river outflow and wind) most likely plays an important role in the occurrence of lower-salinity lenses. The end of spring and beginning of summer should be the most favourable periods for generating intense surface lenses as river runoff decreases and NW winds increase. More in situ data are needed to verify this hypothesis, and a numerical study is essential to allow us to account for the inter-annual variability of the seasonal salinity distribution. As demonstrated in a previous paper (Puillat et al., 2004), the monthly extent of surface low-salinity water $(\mathrm{S}<35)$ varies greatly between years, depending on the monthly dominant wind and/or on mean river runoff (over one to a few months). For instance, in April 1992, when the low-salinity water remained closest to the coast (inshore of the $100 \mathrm{~m}$ isobath), this corresponded to the lowest Gironde and Loire discharges recorded in the 1990s. In April 1999, low-salinity water spread further offshore (at least up to the $200 \mathrm{~m}$ isobath) in response to the synergy of high river runoff over a relatively long period (averaging $\sim 1200$ and $\sim 1600 \mathrm{~m}^{3} \mathrm{~s}^{-1}$ from January to April for the Gironde and Loire respectively) and strong northwesterly wind $\left(\sim 15 \mathrm{~m} \mathrm{~s}^{-1}\right)$ occurring during the first weeks of April. This inter-annual variability is so significant that the seasonal influence of meteorological forcing suggested above should be carefully studied. This variability has also been indirectly observed in a biological study on the environmental conditions for anchovy spawning in the Bay of Biscay (Motos et al., 1996). On an inter-annual scale, Motos et al. (1996) related egg distribution to the inter-annual variability of hydrological conditions by comparing the May-June periods of 1989, 1990, 1991 and 1992.

In view of these considerations, the different scales of hydrodynamic variability over the shelf (mesoscale, seasonal and inter-annual) appear to be interdependent. All these considerations have led us to highlight the importance of hydrological variability on the continental shelf of the Bay of Biscay. A better knowledge of hydrological features is needed to understand the operating cycle of the ecosystems function, and efforts should be made to take account of the different scales of variability by sampling at sea with good resolution (5-10 km between stations) and a highly synoptic strategy.

\section{ACKNOWLEDGEMENTS}

We thank the EPSHOM/CMO (Brest) for allowing us to use the hydrological data presented here, as well as the Plymouth Marine Laboratory Remote Sensing Group, UK (http://www.npm.ac.uk/rsdas/) for SST images, and Schlitzer R. for the Ocean Data View freeware program (http:/www.awi-bremerhaven.de/GEO/ODV/2001). For river runoff data, we thank the French Ministry of Environment's national database for hydrometry and hydrology, the DIREN Centre (service du bassin Loire-Bretagne) and the Bordeaux Port Authority. We also gratefully thank the reviewers for their useful comments.

\section{REFERENCES}

Bartsch, J., A. Lavin and L. Motos. - 1996. A numerical model system to the region around the Iberian Peninsula: model validation and application to hake larvae drift in the Bay of Biscay. ICES CM 1996 (7)-Theme Session S.

Blanton, J.O., L.Y. Oey, J. Amft and T.N. Lee. - 1989. Advection of momentum and buoyancy in a coastal frontal zone. J. Phys. Oceanogr.,19: 98-115.

Chao, S.Y. - 1987. Wind induced motion near the inner shelf fronts. J. Geophys. Res., 92: 3849-3860.

Chao, S.Y. - 1988. Wind-driven motion of estuarine plumes. $J$. Geophys. Res., 18: 1114-1166.

Chen, C. - 2000. A modelling study of episodic cross-frontal water transport over the inner shelf of the South Atlantic Bight. $J$. Geophys. Res., 30: 1722-1742.

Chen, C., L. Zhen and J.O. Blanton. - 1999. Physical processes controlling the formation, evolution, and perturbation of the lowsalinity front in the inner shelf off the southeastern United States: A modelling study. J. Geophys. Res., 104 (C1): 1259-1288.

Froidefond, J.-M., P. Castaing and J.-M. Jouanneau. - 1996. Distribution of suspended matter in a coastal upwelling area. Satellite data and in situ measurements. J. Mar. Sys., 8: 91-105.

Froidefond, J.-M., A.-M. Jégou, J. Hermida, P. Lazure and P. Castaing. - 1998. Variabilité du panache turbide de la Gironde par télédétection. Effets des facteurs climatiques. Oceanol. Acta, 21(2). 191-207.

Herman, A., S. Hinckley, B. Megrey and P. Stabeno. - 1995. Interannual variability of mesoscale eddies and patchiness of young walleye pollock as inferred from a spatially explicit, individual-based model. ICES CM 1995/Q 12, 21 pp.

Hermida, J., P. Lazure, J.M. Froidefond, A.-M. Jégou and P. Castaing. - 1998. La dispersion des apports de la Gironde sur le plateau continental. Données in situ, satellitales et numériques. Oceanol. Acta, 21(2): 209-221.

Hinrichsen, H.-H., A. Lehmann, M. St. John and B. Brügge. - 1997. Modeling the cod larvae drift in the Bornholm Basin in summer 1994. Cont. Shelf Res., 17(14): 1765-1784.

Jégou, A.-M., and P. Lazure. - 1995. Quelques aspects de la circulation sur le plateau atlantique, in: Actas del IV Coloquio 
Internacional sobre Oceanografía del Golfo de Vizcaya, 96-106.

Jezequel, N., R. Mazé and A. Pichon. - 1998. Effect of stratification and vertical velocity on tidal dynamics over a continental slope. Proc. Int. Offshore Polar Eng. Conf., 3(8): 701-709.

Kourafalou, V.H., L.Y. Oey, J.D. Wang and T.N. Lee. - 1996a. The fate of river discharge on the continental shelf: 1, Modeling the river plume and the inner shelf coastal current. J. Geophys. Res., 101: 3415-3434.

Kourafalou, V.H., T.N. Lee, L.Y. Oey and J.D. Wang. - 1996b. The fate of river discharge on the continental shelf: 2, Transport of coastal low salinity water under realistic wind and tidal forcing. J. Geophys. Res., 101: 3435-3455.

Koutsikopoulos, C. and B. Le Cann. - 1996, Physical processes and hydrological structures related to the Bay of Biscay anchovy. Sci. Mar., 60(2-Supp.): 9-19.

Lampert, L., B. Queguiner, T. Labasque, A. Pichon and N. Lebreton. - 2002. Spatial variability of phytoplankton composition and biomass on the eastern continental shelf of the Bay of Biscay (north-east Atlantic Ocean). Evidence for a bloom of Emiliania huxleyi (Prymnesiophyceae) in spring 1998. Cont. Shelf Res., 22: 1225-1247.

Lazure, P. and A.-M. Jégou. - 1998. 3D modelling of seasonal evolution of Loire and Gironde plumes on Biscay bay continental shelf. Oceanol. Acta, 21(2): 165-177.

Le Cann, B. - 1982. Evolution annuelle de la structure hydrologique du plateau continental au sud de la Bretagne: modélisation numérique. Université de Bretagne occidentale, $\mathrm{PhD}$ thesis in physical oceanography, Univ. Brest.

Le Cann, B. - 1990. Barotropic tidal dynamics of the bay of Biscay shelf: observations, numerical modelling and physical interpretation. Cont. Shelf Res., 10(8): 723-758.

Le Cann, B. and R. Pingree. - 1995. Circulation dans le Golfe de Gascogne: une revue des travaux récents, in Acta del IV Coloquio Internacional sobre Oceanografía del Golfo de Vizcaya, 217-234.

Le Cann, B., J.P. Girardot and J.C. Poulard. - 1997. SEFOS Drifting Buoys in the bay of Biscay area: Final report, January 1997.

Lee, T.N., C. Rooth, E. Williams, M. McGowen, A.F. Szmant and M.E. Clarke. - 1992. Influence of Florida current, gyres and wind-driven circulation on transport of larvae and recruitment in the Florida Key coral reef. Cont. Shelf Res., 12: 971-1002.

Lee, T.N., M.E. Clarke, E. Williams, A.F. Szmant and T. Berger. 1994. Evolution of the Tortugas gyre and its influence on recruitment in the Florida Key. Bull. Mar. Sci., 54(3): 621-646.

Mazé, R. - 1987. Generation and propagation of non linear internal waves induced by the tyde over a continental slope. Cont. Shelf Res., 7: 1079-1104.

Motos, L., A. Uriarte and V. Valencia. - 1996. The spawning environment of the Bay of Biscay anchovy (Engraulis encrasicolus L.). Sci. Mar., 60(Supp. 2): 117-140.

Oey, L.Y. - 1986. The formation and maintenance of density fronts on the U.S. southeastern continental shelf during winter. $J$ Phys. Oceanogr. 16: 1221-1135.

Paffenhöfer, G.A., L.P. Atkinson, T.N. Lee, J.O. Blanton, B.K.
Sherman, T.B. Stewart. - 1994. Variability of particulate matter and abundant zooplankton off the southeastern United States during spring of 1984 and 1985. Cont. Shelf Res., 14: 629-654.

Palomera, I. - 1992. Spawning of anchovy Engraulis encrasicolus L., in the Northwestern Mediterranean relative to hydrographic features in the region. Mar. Ecol. Prog. Ser., 79: 215-223.

Penven, P., C. Roy, A. Colin de Verdière and J. Largier. - 2000 Simulation of a coastal jet retention process using a barotropic model. Oceanol. Acta, 23 (5): 615-634.

Pingree, R.D. - 1984. Some applications of remote sensing to studies in the bay of Biscay, Celtic sea and English channel. Remote sensing of the shelf sea hydrodynamics, Proceeding of the 15th International Liege Colloquium on Ocean Hydrodynamics. Elsevier Oceanography series, 38: 285-315.

Pingree, R.D. and B. Le Cann. - 1989. Celtic and Armorican slope and residual currents. Prog. Oceanogr., 23: 303-338.

Pingree, R.D. and B. Le Cann. - 1990.Structure, strength and seasonality of the slope currents in the bay of Biscay region. $J$. Mar. Biol. Ass. U.K., 70: 857-885.

Pingree, R.D. and B. Le Cann. - 1992. Three anticyclonic Slope Water Oceanic eDDIES (SWODDIES) in the southern bay of Biscay in 1990. Deep-Sea Res., 39 (7/8): 1147-1175.

Pingree, R.D., G.D. Mardell, P.M. Holligan, D.K. Griffiths and J. Smithers. - 1982. Celtic Sea and Armorican current structure and the vertical distributions of temperature and chlorophyll. Cont. Shelf Res., 1(1): 99-116.

Porch, C.E. - 1998. A numerical study of larval fish retention along the southeast Florida coast, Ecol. Model., 109(1): 35-59.

Puillat, I., P. Lazure, A.-M. Jégou and L. Lampert. - 2003. Mesoscale, interannual and seasonal hydrological variability over the French continental shelf of the Bay of Biscay during the 1990s, ICES Mar. Sci. Symp., 219: 333-336.

Puillat, I., P. Lazure, A.-M. Jégou, L. Lampert and P.I. Miller. 2004. Hydrographical varaibility on the French continental shelf in the Bay of Biscay, during the 1990s, Cont. Shelf Res. 25: 1143-1163.

Schumacher, J.D., P.J. Stabeno and S.J., Bograd. - 1993 Characteristics of an eddy over the continental shelf: Shelikov Strait, Alaska. J. Geophys. Res., 98: 8395-8404.

Sánchez, F. and Gil, J. - 2000. Hydrographic mesoscale structures and Poleward Current as a determinant of hake (Merluccius merluccius) recruitment in southern Bay of Biscay, ICES J. Mar. Sci., 57(1): 152-170.

Uriarte, A., Y. Sagaraminaga, C. Scalabrin, V. Valencia, P. Cermeno, E. De Miguel, J.A.G. Sanchez and M. Jimenez. 2001. Ecology of anchovy juveniles in the Bay of Biscay 4 months after peak spawning: Do they form part of the plankton? Int. Counc. For the Exploration of the Sea. Paleagade 2-4 DK1261 Copenhagen (Danemark).

Van Aken, H.M. - 2001. The hydrography of the mid-latitude Northeast Atlantic Ocean. Part III: the subducted thermocline water mass. Deep-Sea Res. I, 48: 237-267.

Received July 8, 2002. Accepted December 3, 2004. 